\title{
THERMAL ANALYSES OF SODALITE, TUGTUPITE, DANALITE AND HELVITE
}

\author{
SYTLE M. ANTAO \\ Department of Geosciences, State University of New York, Stony Brook, New York 11794-2100, U.S.A. \\ ISHMAEL HASSAN $\$$ \\ Department of Chemistry, University of the West Indies, Mona, Kingston 7, Jamaica
}

\begin{abstract}
Differential thermal analyses (DTA) and thermogravimetric analyses (TG) were carried out on sodalite, tugtupite, danalite, and helvite using a Netzsch STA $409 \mathrm{EP} / 3 / \mathrm{D}$ simultaneous TG-DTA apparatus. In the DTA and TG experimental run, a weighed amount of finely powdered sample was heated from 20 to $1450^{\circ} \mathrm{C}$ at a constant rate of $5^{\circ} \mathrm{C} / \mathrm{min}$. Sodalite, $\mathrm{Na}_{8}\left[\mathrm{Al}_{6} \mathrm{Si}_{6} \mathrm{O}_{24}\right] \mathrm{Cl}_{2}$, melts at $1079^{\circ} \mathrm{C}$. The $\mathrm{NaCl}$ component in the sodalite-derived melt is lost in two stages; about $4.5 \mathrm{wt} \%$ of $\mathrm{NaCl}$ is lost slowly at about $1150^{\circ} \mathrm{C}$, and about 7.0 wt. $\%$ of $\mathrm{NaCl}$ is lost at a faster rate at about $1284^{\circ} \mathrm{C}$. The interpretation that the $\mathrm{NaCl}$ component behaves this way in sodalite is confirmed by DTA and TG analyses of halite. Tugtupite, $\mathrm{Na}_{8}\left[\mathrm{Al}_{2} \mathrm{Be}_{2} \mathrm{Si}_{8} \mathrm{O}_{24}\right] \mathrm{Cl}_{2}, \mathrm{melts}$ at $1029^{\circ} \mathrm{C}$. The $\mathrm{NaCl}$ component in tugtupite is lost in two main stages; about $1.8 \mathrm{wt} . \%$ of $\mathrm{NaCl}$ is first lost at about $1007^{\circ} \mathrm{C}$, and about 8.2 wt. $\%$ of $\mathrm{NaCl}$ is lost in several steps between about 1018 and about $1442^{\circ} \mathrm{C}$. Danalite, ideally $\mathrm{Fe}_{8}\left[\mathrm{Be}_{6} \mathrm{Si}_{6} \mathrm{O}_{24}\right] \mathrm{S}_{2}$, and helvite, ideally $\mathrm{Mn}_{8}\left[\mathrm{Be}_{6} \mathrm{Si}_{6} \mathrm{O}_{24}\right] \mathrm{S}_{2}$, undergo an oxidation of $(\mathrm{Mn}, \mathrm{Fe})^{2+}$ to $(\mathrm{Mn}, \mathrm{Fe})^{3+}$ cations. This is followed by a loss of $\mathrm{S}_{2}(\mathrm{~g})$, and then melting at about $1060^{\circ} \mathrm{C}$. Finally, there is another oxidation of $\mathrm{Mn}^{3+}$ to $\mathrm{Mn}^{4+}$. These oxidations occur because the samples were heated in a static air environment. The first oxidation in danalite and helvite begins at about 771 and $705^{\circ} \mathrm{C}$, respectively. Danalite gains $4.0 \mathrm{wt} . \%$, whereas helvite gains $5.0 \mathrm{wt} . \%$ in the first weight-gain stage. In the weight-loss stage, danalite loses $5.7 \mathrm{wt} . \%$ of $\mathrm{S}_{2}(\mathrm{~g})$ from about $1029^{\circ} \mathrm{C}$, whereas helvite loses $4.7 \mathrm{wt} . \%$ of $\mathrm{S}_{2}(\mathrm{~g})$ from about $883^{\circ} \mathrm{C}$. The second stage of oxidation begins at about $1300^{\circ} \mathrm{C}$ in both the danalite- and helvite-derived melts. At this stage, the weight gain in the danalite-derived melt is about $0.7 \%$, whereas that in the helvite-derived melt is about $0.2 \%$.
\end{abstract}

Keywords: sodalite, tugtupite, danalite, helvite, differential thermal analysis, thermogravimetric analysis.

\section{SOMMAIRE}

Nous avons étudié la sodalite, la tugtupite, la danalite et la helvite par analyses thermique différentielle (ATD) et thermogravimétrique (TG) en utilisant un appareil Netzsch STA 409 EP/3/D. Pour ces expériences, nous nous sommes servis d'une quantité connue d'échantillon finement pulvérisé, chauffé à partir de 20 jusqu'à $1450^{\circ} \mathrm{C}$ à un taux constant de $5^{\circ} \mathrm{C} / \mathrm{min}$. La sodalite, $\mathrm{Na}_{8}\left[\mathrm{Al}_{6} \mathrm{Si}_{6} \mathrm{O}_{24}\right] \mathrm{Cl}_{2}$, atteint son point de fusion à $1079^{\circ} \mathrm{C}$. La composante $\mathrm{NaCl}$ du bain fondu se volatilise en deux étapes; environ $4.5 \%$ (poids) de $\mathrm{NaCl}$ est perdu lentement près de $1150^{\circ} \mathrm{C}$, et environ $7.0 \%$ est perdu plus rapidement près de $1284^{\circ} \mathrm{C}$. Notre interpretation à propos de la sodalite est confirmée par analyses ADT et TG de la halite. La tugtupite, $\mathrm{Na}_{8}\left[\mathrm{Al}_{2} \mathrm{Be}_{2} \mathrm{Si}_{8} \mathrm{O}_{24}\right] \mathrm{Cl}_{2}$, fond à $1029^{\circ} \mathrm{C}$. La composante $\mathrm{NaCl}$ de la tugtupite se volatilise en deux étapes; environ $1.8 \%$ de $\mathrm{NaCl}$ se perd près de $1007^{\circ} \mathrm{C}$, et environ $8.2 \%$ de $\mathrm{NaCl}$ se perd en plusieurs étapes entre 1018 et $1442^{\circ} \mathrm{C}$. La danalite, dont la composition idéale est $\mathrm{Fe}_{8}\left[\mathrm{Be}_{6} \mathrm{Si}_{6} \mathrm{O}_{24}\right] \mathrm{S}_{2}$, et la helvite, $\mathrm{Mn}_{8}\left[\mathrm{Be}_{6} \mathrm{Si}_{6} \mathrm{O}_{24}\right] \mathrm{S}_{2}$, subissent une oxydation de $(\mathrm{Mn}, \mathrm{Fe})^{2+}$ à $(\mathrm{Mn}, \mathrm{Fe})^{3+}$. Cette transformation est suivie d'une perte de $\mathrm{S}_{2}(\mathrm{~g})$, et de la fusion à environ $1060^{\circ} \mathrm{C}$. Enfin, il y a une oxydation plus poussée de $\mathrm{Mn}^{3+}$ à $\mathrm{Mn}^{4+}$. Ces étapes d'oxydation sont le résultat du chauffage des échantillons dans l'air, dans un milieu statique. La première étape d'oxydation de la danalite et de la helvite débute à environ 771 et $705^{\circ} \mathrm{C}$, respectivement. La danalite augmente en poids de $4.0 \%$, tandis que la helvite augmente de $5.0 \%$. Suit ensuite une perte de poids, $5.7 \%$ sous forme de $\mathrm{S}_{2}(\mathrm{~g})$ pour la danalite à partir de $1029^{\circ} \mathrm{C}$, et $4.7 \%$ de $\mathrm{S}_{2}(\mathrm{~g})$ à partir de $883^{\circ} \mathrm{C}$ pour la helvite. Le second stade d'oxydation débute à environ $1300^{\circ} \mathrm{C}$ dans les liquides dérivés de la danalite et de la helvite. L'augmentation en poids à ce stade est d'environ $0.7 \%$ pour le cas de la danalite et $0.2 \%$ pour le cas de la helvite.

(Traduit par la Rédaction)

Mots-clés: sodalite, tugtupite, danalite, helvite, analyse thermique différentielle, analyse thermogravimétrique.

§ E-mail address: ishmael.hassan@uwimona.edu.jm 


\section{INTRODUCTION}

Our aim in this study is to determine the thermal behavior of sodalite, tugtupite, danalite, and helvite using differential thermal analysis (DTA) and thermogravimetry (TG) techniques. The types of volatiles liberated and the temperatures at which liberation occurs are determined, among other features.

In sodalite and tugtupite, $\mathrm{Cl}$ and possibly $\mathrm{Na}$ are important volatile constituents that may be liberated on heating. If the formula of sodalite is written as $\mathrm{Na}_{8}\left[\mathrm{Al}_{6} \mathrm{Si}_{6} \mathrm{O}_{24}\right] \mathrm{Cl}_{2}$, then $\mathrm{Cl}_{2}$ (g) could be expected to be liberated on heating; however, if the sodalite formula is written as $\mathrm{Na}_{6}\left[\mathrm{Al}_{6} \mathrm{Si}_{6} \mathrm{O}_{24}\right] \cdot 2 \mathrm{NaCl}$, then $\mathrm{NaCl}$ could be liberated on heating; similarly for tugtupite, $\mathrm{Na}_{8}\left[\mathrm{Al}_{2} \mathrm{Be}_{2}\right.$ $\left.\mathrm{Si}_{8} \mathrm{O}_{24}\right] \mathrm{Cl}_{2}$, which can be written as $\mathrm{Na}_{6}\left[\mathrm{Al}_{2} \mathrm{Be}_{2} \mathrm{Si}_{8}\right.$ $\left.\mathrm{O}_{24}\right] \cdot 2 \mathrm{NaCl}$. This study was carried out to determine which chemical constituents are liberated on heating, to
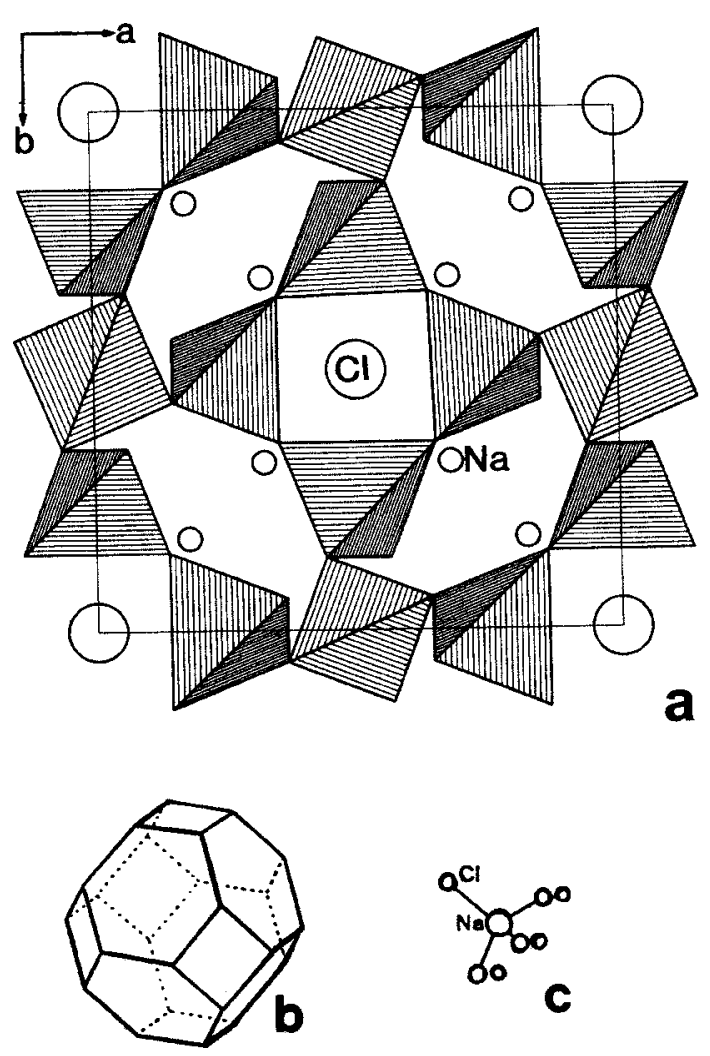

FIG. 1. (a) Projection of the unit cell of the sodalite structure down [001], drawn using the program STRUPLO. (b) The truncated cubo-octahedral or $\beta$-cage in sodalite. (c) Fourfold (trigonal pyramid) coordination of the Na site in sodalite. measure the temperature where changes take place, and to compare the results for sodalite and tugtupite. If $\mathrm{NaCl}$ is liberated, then it would be of interest to compare the results for sodalite and tugtupite with those for halite, $\mathrm{NaCl}$. For this purpose, halite also was analyzed by the differential thermal analysis (DTA) and thermogravimetric analysis (TG) techniques.

From the chemical composition of danalite and helvite, $\mathrm{S}$ is an important volatile that could be liberated on heating. Therefore, this study on danalite and helvite was carried out to determine the temperature where $\mathrm{S}_{2}(\mathrm{~g})$ is liberated, and to determine the temperatures at which other structural changes may occur.

\section{Review of the Structural Aspects}

The frameworks of tugtupite, danalite, helvite, lazurite, nosean, and haïyne, which has the sodalite structure, consist of $T \mathrm{O}_{4}$ tetrahedra $\left(T=\mathrm{Si}^{4+}, \mathrm{Al}^{3+}\right.$, and $\left.\mathrm{Be}^{2+}\right)$, which are linked at the corners and give rise to large cages (Fig. 1). These tetrahedra are fully ordered. The aluminosilicate framework of cubic sodalite, ideally $\mathrm{Na}_{8}\left[\mathrm{Al}_{6} \mathrm{Si}_{6} \mathrm{O}_{24}\right] \mathrm{Cl}_{2}$, is characterized by parallel sixmembered rings consisting of alternating $\mathrm{AlO}_{4}$ and $\mathrm{SiO}_{4}$ tetrahedra. The cubic symmetry is the result of the stacking of such six-membered rings in an $A B C A B C \ldots$ sequence, which leads to large cages that are bounded by eight six-membered rings parallel to $\{111\}$ planes and six four-membered rings parallel to $\{001\}$ planes. The four-membered rings also consist of alternating $\mathrm{AlO}_{4}$ and $\mathrm{SiO}_{4}$ tetrahedra (Fig. 1a). The sodalite or $\beta$-cages enclose $\left[\mathrm{Na}_{4}{ }^{\bullet} \mathrm{Cl}\right]^{3+}$ clusters (Figs. 1b, c). The structure of tugtupite (tetragonal), ideally $\mathrm{Na}_{8}\left[\mathrm{Al}_{2} \mathrm{Be}_{2} \mathrm{Si}_{8} \mathrm{O}_{24}\right] \mathrm{Cl}_{2}$, is isotypic with that of sodalite. The $\beta$-cages in tugtupite also enclose $\left[\mathrm{Na}_{4}{ }^{\bullet} \mathrm{Cl}\right]^{3+}$ clusters, as in sodalite (Hassan \& Grundy 1991). The sodalite-group minerals were studied by several researchers (e.g., Pauling 1930, Löns \& Schulz 1967, Taylor 1967, 1968, Danø 1966, Peterson 1983, Hassan \& Grundy 1984, 1991).

The helvite-group minerals, $(\mathrm{Mn}, \mathrm{Fe}, \mathrm{Zn})_{8}\left[\mathrm{Be}_{6} \mathrm{Si}_{6}\right.$ $\left.\mathrm{O}_{24}\right] \mathrm{S}_{2}$, are also isotypic with sodalite. The Mn-rich member is helvite, the Fe-rich member is danalite, and the $\mathrm{Zn}$-rich member is genthelvite. These minerals were also studied by several researchers (e.g., Hassan \& Grundy 1985, Barth 1926, Burt 1980, Dunn 1976). The $\beta$-cages in the helvite-group minerals enclose clusters of $\left[(\mathrm{Mn}, \mathrm{Fe}, \mathrm{Zn})_{4} \cdot \mathrm{S}\right]^{6+}$. Because these clusters are highly charged (i.e., 6+ valence units), they have smaller sizes than the $\left[\mathrm{Na}_{4}{ }^{\bullet} \mathrm{Cl}\right]^{3+}$ clusters of sodalite and tugtupite (Hassan \& Grundy 1985, 1991). The dimensions of the framework tetrahedra in the helvite-group minerals are constant regardless of the nature of the interframework cation because of the rotational freedom of the framework tetrahedra (Hassan \& Grundy 1985). In particular, pure danalite consists of $100 \%\left[\mathrm{Fe}_{4}{ }^{\bullet} \mathrm{S}\right]^{6+}$ clusters, and pure helvite consists of $100 \%\left[\mathrm{Mn}_{4}{ }^{\bullet} \mathrm{S}\right]^{6+}$ clusters. These two minerals are investigated in this study. 


\section{EXPERIMENTAL}

The samples of sodalite, tugtupite, danalite, and helvite were crushed, and pure crystals were handpicked and crushed to a powder using an agate mortar and pestle. A portion of the powder was used for the DTA and TG analyses, and another portion was used for hightemperature X-ray-diffraction (XRD) analyses. The results will be published elsewhere (Antao \& Hassan, in prep.). The samples used in this study were also used by Hassan \& Grundy $(1984,1985,1991)$ to refine their crystal structures; they thus are well characterized. The composition of the samples used is presented in Table 1.

The experiments were carried out with a Netzsch STA 409 EP/3/D simultaneous TG-DTA instrument. The data were analyzed using software programs supplied with the instrument (Hassan 1996). The thermogravimetric (TG) curve was corrected for buoyancy effect, and the differential thermal analysis (DTA) curve was corrected for baseline effect. Corrections for buoyancy and baseline effects were obtained in a blank run using empty crucibles that were later used to run the sample in a second run, but the two experimental runs were made under identical conditions. The relationship between change in enthalpy and peak area in the DTA curve was determined by calibration using various standard materials.

\section{RESUlTS AND DiscUSSION}

Sodalite, $\mathrm{Na}_{8}\left[\mathrm{Al}_{6} \mathrm{Si}_{6} \mathrm{O}_{24}\right] \mathrm{Cl}_{2}$

The blue sodalite sample used in this study is from the Princess mine, Bancroft, Ontario. Its chemical com- position is given in Table 1. For the thermal analyses, $98.7 \mathrm{mg}$ of finely powdered sodalite sample was used. The TG and DTA curves and their corresponding derivative curves (DTG and DDTA, respectively) for sodalite are shown in Figure 2. The temperature range from 20 to $850^{\circ} \mathrm{C}$ did not lead to any significant change in weight or peaks, and is therefore left out of Figure 2. The DTG and DDTA curves are obtained from the raw TG and DTA data, respectively, using a narrow window for filtering the measured raw data. The differentiation was done by using a modified Golay-Savitzky algorithm of second order. Sodalite data obtained from these curves are summarized in Table 2 .

Four peaks are observed in the DTA curve; peaks 1, 3 , and 4 are well defined in both the DTA and DDTA curves, but peak 2 , although visually detectable, is less obvious in the DTA curve, but is clearly seen in the DTG curve (Fig. 2, Table 2). At $1079^{\circ} \mathrm{C}$, peak 1 occurs only in the DTA trace, but there is no loss in weight in the TG curve. Peak 1 thus is related to melting (Fig. 2a). At $1347^{\circ} \mathrm{C}$, peak 4 also occurs only in the DTA trace, and there is no loss in weight; we have no explanation for the cause of peak 4 (Fig. 2a). After the experiment, the residue in the crucible was found to be a porous powder that was easily removed just by tapping the crucible on a desk. This is in contrast to the residue observe for the other minerals, where the product of melting is a glass. Wellman (1970) studied the stability of sodalite in the range of $500-700^{\circ} \mathrm{C}$ and $600-2000$ bars fluid pressure and indicated that sodalite is stable on the vapor-saturated liquidus, so sodalite can be a magmatic mineral.

There are two well-defined DTG peaks, 2 and 3 (Table 2, Fig. 2b). A continuous loss in weight occurs over peaks 2 and 3 and corresponds to a net loss in

TABLE 1. CHEMICAL COMPOSITION OF SODALITE, TUGTUPITE, DANALITE, AND HELVITE

\begin{tabular}{|c|c|c|c|c|c|c|c|c|c|c|c|c|}
\hline & \multicolumn{3}{|c|}{ Sodalite } & \multicolumn{3}{|c|}{ Tugtupite } & \multicolumn{3}{|c|}{ Danalite } & \multicolumn{3}{|c|}{ Helvite } \\
\hline & wt. $\%$ & & $a p f u t$ & wt.\% & & apfiu $\ddagger$ & wt. $\%$ & & apfi* & wt.\% & & $f u \S$ \\
\hline $\mathrm{SiO}_{2}$ & 36.55 & $\mathrm{Si}$ & 5.93 & 51.58 & $\mathrm{Si}$ & 7.98 & 30.56 & $\mathrm{Si}$ & 5.83 & 32.47 & $\mathbf{S i}$ & 6 \\
\hline $\mathrm{Al}_{2} \mathrm{O}_{3}$ & 31.78 & $\mathrm{Al}$ & 6.07 & 11.15 & Al & 2.03 & 0.10 & Al & 0.02 & & & \\
\hline $\mathrm{BeO}$ & & & & 5.40 & $\mathrm{Be}$ & 2.00 & 13.40 & $\mathrm{Be}$ & 6.14 & 13.52 & $\mathrm{Be}$ & 6 \\
\hline $\mathrm{Na}_{2} \mathrm{O}$ & 25.30 & $\mathrm{Na}$ & 7.95 & 25.52 & $\mathrm{Na}$ & 7.62 & & & & & & \\
\hline $\mathrm{CaO}$ & 0.25 & $\mathrm{Ca}$ & 0.04 & & & & 0.05 & $\mathrm{Ca}$ & 0.01 & & & \\
\hline $\mathrm{K}_{2} \mathrm{O}$ & 0.10 & $\mathbf{K}$ & 0.02 & 0.12 & $\mathbf{K}$ & 0.02 & & & & & & \\
\hline $\mathrm{Fe}_{2} \mathrm{O}_{3}$ & 0.19 & $\mathrm{Fe}$ & 0.02 & & & & & & & & & \\
\hline $\mathrm{MnO}$ & 0.01 & $\mathrm{Mn}$ & 0.00 & & & & 24.97 & Mn & 4.04 & 51.12 & $\mathrm{Mn}$ & 8 \\
\hline $\mathrm{FeO}$ & & & & & & & 24.00 & $\mathrm{Fe}$ & 3.83 & & & \\
\hline $\mathrm{ZnO}$ & & & & & & & 4.13 & $\mathrm{Zn}$ & 0.58 & & & \\
\hline $\mathrm{MgO}$ & 0.19 & $\mathrm{Mg}$ & 0.05 & 0.20 & $\mathbf{M g}$ & 0.05 & & & & & & \\
\hline $\mathrm{Cl}$ & 7.17 & $\mathrm{Cl}$ & 1.97 & 7.28 & $\mathrm{Cl}$ & 1.90 & & & & & & \\
\hline $\mathbf{S}$ & 0.02 & $\mathbf{S}$ & 0.01 & 0.33 & $\mathrm{~S}$ & 0.09 & 5.73 & $\mathbf{S}$ & 2.05 & 5.78 & $\mathbf{S}$ & 2 \\
\hline $\mathrm{O}-\mathrm{Cl}, \mathrm{S}$ & -1.62 & & & -1.99 & & & -2.86 & & & -2.88 & & \\
\hline Total & 99.54 & & & 99.59 & & & 100.08 & & & 100.01 & & \\
\hline
\end{tabular}

$\uparrow$ Composition from Hassan \& Grundy (1984), based on $\mathrm{Al}+\mathrm{Si}=12$ atoms per formula unit (apfu). $¥$ Composition from Danø (1966), based on $\mathrm{Al}+\mathrm{Be}+\mathrm{Si}=12$ apfu. $*$ Composition from Dunn (1976), based on $\mathrm{Al}+\mathrm{Be}+\mathrm{Si}=12$ apfu. $\S$ Theoretical composition of pure helvite. Tugtupite: sample ROM \# M32790. Danalite: sample ROM \# M37261. 
weight of about $11.5 \%$. This continuous weight-loss can be somewhat arbitrarily divided into two steps, with a slow loss of about $4.5 \mathrm{wt} . \%$ for peak 2 , and a more rapid loss of about 7.0 wt.\% for peak 3 (Fig. 2b). In the sodalite formula, $\mathrm{Na}_{6}\left[\mathrm{Al}_{6} \mathrm{Si}_{6} \mathrm{O}_{24}\right] \cdot 2 \mathrm{NaCl}$, the $2 \mathrm{NaCl}$ component constitutes $12.1 \mathrm{wt} . \%$, which is comparable to the total loss in weight of about $12.2 \%$ obtained experimentally (Table 2). According to the chemical data on sodalite, $\mathrm{Cl}$ constitutes 7.17 wt.\% (Table 1), so 4.93 wt. \% loss of $\mathrm{Na}$ is required for the total weight-loss to be about $12.1 \%$. Moreover, the TG results indicate that $\mathrm{NaCl}$ was lost at two different rates. To investigate the results of sodalite further, halite was thermally analyzed.
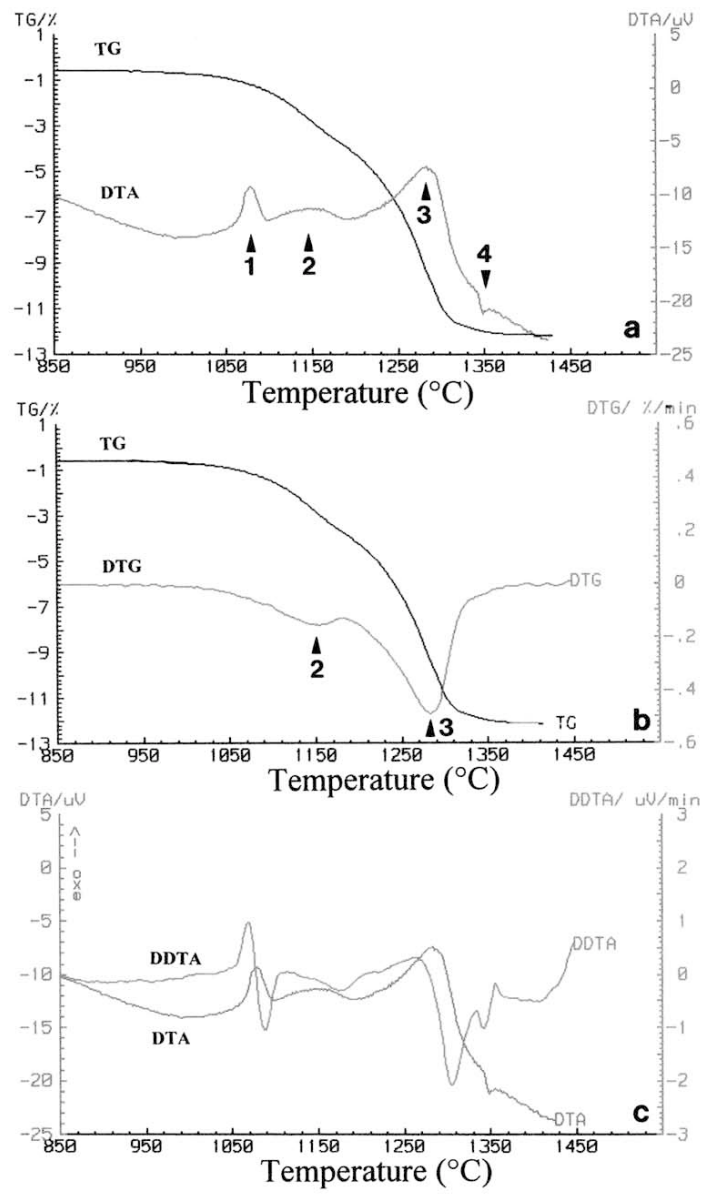

FIG. 2. Thermal curves for sodalite: (a) TG and DTA curves, (b) TG and DTG curves, and (c) DTA and DDTA curves. Corresponding peaks at a particular temperature are given the same number and are labeled on the DTA and DTG curves in this and the other figures that contain thermal curves.

\section{Halite, $\mathrm{NaCl}$}

For the thermal analyses of halite, $43.0 \mathrm{mg}$ of the sample was used. The thermal curves for halite are shown in Figure 3, and the data from these curves are summarized in Table 3. Three peaks are observed in the DTA curve (Figs. 3a, c); peaks 1 and 3 are well defined in both the DTA and DDTA curves, but peak 2, although visually detectable, is less obvious in the DTA curve, but is clearly seen in the DTG curve. At $803^{\circ} \mathrm{C}$, peak 1 occurs only in the DTA trace, and there is no loss in weight. Peak 1 is thus attributed to the melting of $\mathrm{NaCl}$. This melting point is very close to that reported, $800^{\circ} \mathrm{C}$, in the literature (e.g., Neuman 1977).

Peaks 2 and 3 in the thermal curves correspond to loss of volatiles. The $\mathrm{TG}$ curve of $\mathrm{NaCl}$ shows that practically all the mass is lost (Table 3 ). A continuous loss of weight occurs over peaks 2 and 3 and corresponds to a net loss in weight of about $98.5 \%$. This continuous weight-loss may somewhat arbitrarily be divided into two steps, with losses of about $38.7 \mathrm{wt} . \%$ for peak 2 and 59.5 wt. \% for peak 3 (Fig. 3b); the loss of $\mathrm{NaCl}$ is slower in the first step compared to the second step.

The DTA and TG results for halite and sodalite are similar to each other with regard to the three peaks (1, 2 , and 3). In both samples, $\mathrm{NaCl}$ is liberated at two different rates. Peaks 2 and 3 in both samples are attributed to the loss of $\mathrm{NaCl}$ at different rates; peak 2 corresponds to a slow rate of loss, and peak 3 , to a more rapid rate of loss.

TABLE 2. DATA DERIVED FROM TG, DTG, DTA, AND DDTA ANALYSES OF SODALITE

\begin{tabular}{|c|c|c|c|c|c|c|}
\hline Peaks & Miscellaneous & TG & DTG & DTA & DDTA & Changes \\
\hline $\begin{array}{l}\text { Peak } 1 \\
(+) \text { ve }\end{array}$ & $\begin{array}{l}\text { Onset T }\left({ }^{\circ} \mathrm{C}\right) \\
\text { Peak } \mathrm{T}\left({ }^{\circ} \mathrm{C}\right) \\
\text { End } \mathrm{T}\left({ }^{\circ} \mathrm{C}\right) \\
\% \text { wt. loss } \\
\text { Enthalpy }(\mathrm{J} / \mathrm{g})\end{array}$ & --- & & $\begin{array}{l}1064 \\
1079 \\
1093 \\
\\
59.94\end{array}$ & $\begin{array}{l}1068 \\
1088\end{array}$ & Melting \\
\hline $\begin{array}{l}\text { Peak } 2 \\
(+) \text { ve }\end{array}$ & $\begin{array}{l}\text { Onset T }\left({ }^{\circ} \mathrm{C}\right) \\
\text { Peak T }\left({ }^{\circ} \mathrm{C}\right) \\
\text { End T }\left({ }^{\circ} \mathrm{C}\right) \\
\% \text { wt. loss } \\
\text { Enthalpy }(\mathrm{J} / \mathrm{g})\end{array}$ & $\begin{array}{r}933 \\
\\
1224 \\
4.5\end{array}$ & $\begin{array}{l}1019 \\
1150 \\
1180\end{array}$ & $\begin{array}{l}1093 \\
1148 \\
1190 \\
69.72\end{array}$ & 1173 & $\begin{array}{l}\text { Loss of } \\
\mathrm{NaCl} \text { is } \\
\text { slow }\end{array}$ \\
\hline $\begin{array}{l}\text { Peak } 3 \\
(+) \text { ve }\end{array}$ & $\begin{array}{l}\text { Onset T }\left({ }^{\circ} \mathrm{C}\right) \\
\text { Peak T }\left({ }^{\circ} \mathrm{C}\right) \\
\text { End T }\left({ }^{\circ} \mathrm{C}\right) \\
\% \text { wt. loss } \\
\text { Enthalpy }(\mathrm{J} / \mathrm{g})\end{array}$ & $\begin{array}{r}1224 \\
\\
1384 \\
7.0\end{array}$ & $\begin{array}{l}1180 \\
1284 \\
1322\end{array}$ & $\begin{array}{l}1190 \\
1287 \\
1319 \\
\\
2.68\end{array}$ & $\begin{array}{l}1261 \\
1306\end{array}$ & $\begin{array}{l}\text { Loss of } \\
\mathrm{NaCl} \text { is } \\
\text { more } \\
\text { rapid }\end{array}$ \\
\hline $\begin{array}{l}\text { Peak } 4 \\
(-) \text { ve }\end{array}$ & $\begin{array}{l}\text { Onset T }\left({ }^{\circ} \mathrm{C}\right) \\
\text { Peak T }\left({ }^{\circ} \mathrm{C}\right) \\
\text { End T }\left({ }^{\circ} \mathrm{C}\right) \\
\% \text { wt. loss } \\
\text { Enthalpy }(\mathrm{J} / \mathrm{g})\end{array}$ & --- & & $\begin{array}{r}1342 \\
1347 \\
1354 \\
-0.07\end{array}$ & $\begin{array}{l}1342 \\
1356\end{array}$ & $?$ \\
\hline Total ${ }^{*}$ & Peaks 2 and 3 : & vt. $\%$ & & & & \\
\hline
\end{tabular}

* Total \% wt. loss from beginning to end is 12.2 , including 0.7 at the beginning $\uparrow$ Positive: exothermic peak, negative: endothermic peak in this and other similar tables. 
Tugtupite, $\mathrm{Na}_{8}\left[\mathrm{Al}_{2} \mathrm{Be}_{2} \mathrm{Si}_{8} \mathrm{O}_{24}\right] \mathrm{Cl}_{2}$

The red tugtupite sample is from Ilímaussaq, Narssaq Kommune, South Greenland (Royal Ontario Museum, ROM \#M32790). Table 1 contains the chemical data for a sample from the same locality (Danø 1966). For the thermal analyses, $103.0 \mathrm{mg}$ of the finely powdered tugtupite sample was used. The thermal curves for tugtupite are shown in Figure 4. The temperature range from 20 to $850^{\circ} \mathrm{C}$ did not show any significant change in weight or peaks, and are therefore left out of Figure 4. Data for tugtupite obtained from these curves are summarized in Table 4. Many peaks are observed in the DTA and DDTA curves. At $1029^{\circ} \mathrm{C}$, peak 2 occurs only in the DTA trace, and there is no loss in weight in the TG curve. Peak 2 thus is related to melting. Note that
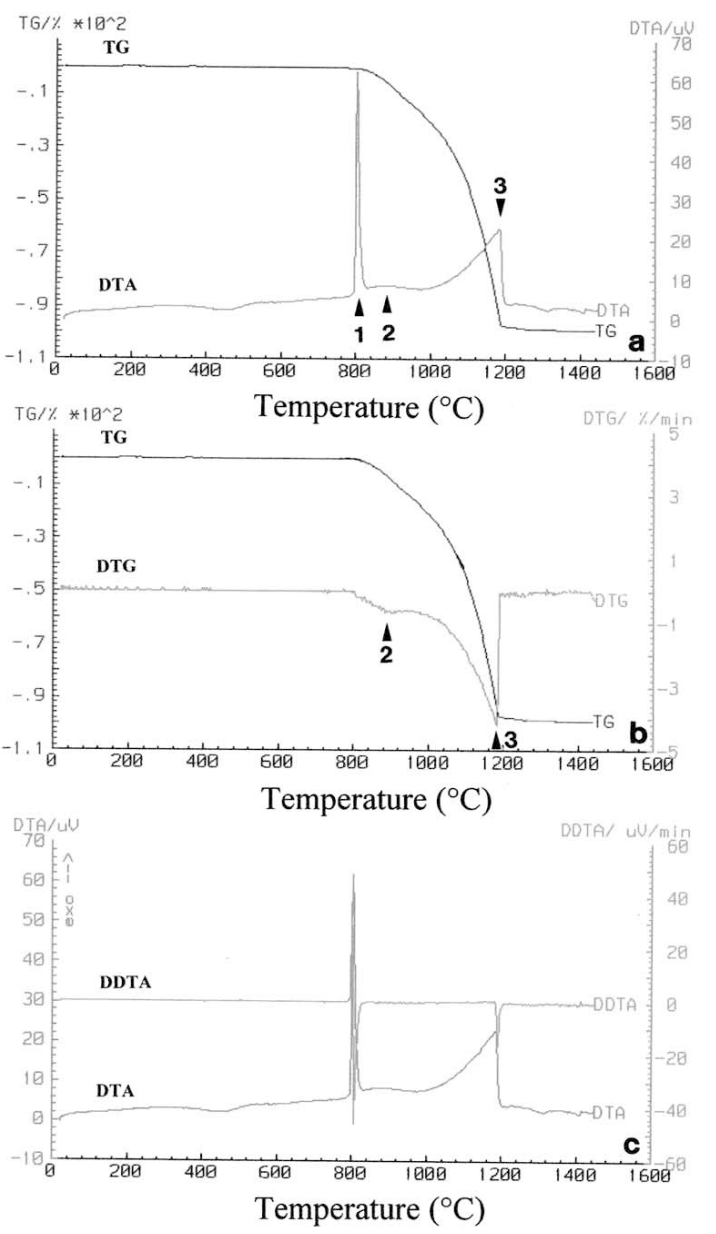

FIG. 3. Thermal curves for halite: (a) TG and DTA curves, (b) TG and DTG curves, and (c) DTA and DDTA curves. peak 2 in the DTA curve also encloses peak 1, which corresponds to a weight-loss step. Thus, peaks 1 and 2, which are well separated in sodalite, overlap in tugtupite (Figs. 2a, 4a). It should be noted that both the DTA and DTG curves are mirror images of each other. However, the DTG curve only contains peaks corresponding to weight loss, whereas the DTA curve contains these peaks in addition to peaks corresponding to transitions. Signs of melting (i.e., glass) were observed in the crucible after the experiment.

Several DTG peaks were observed (Fig. 4b). The weight loss can be divided into two main steps, with losses of about $1.8 \mathrm{wt} . \%$ for peak 1 and $8.2 \mathrm{wt} . \%$ for all the other peaks beyond $1250^{\circ} \mathrm{C}$. All the TG peaks correspond to a net loss in weight of about $10.0 \%$. These weight losses are attributed to the escape of $\mathrm{NaCl}$. According to the chemical analyses, $\mathrm{Cl}$ constitutes 7.28 wt.\% (Table 1), so $2.72 \mathrm{wt} \%$ loss of $\mathrm{Na}$ is required for the total weight loss to be about $10.0 \%$. In the tugtupite formula, $\mathrm{Na}_{6}\left[\mathrm{Al}_{2} \mathrm{Be}_{2} \mathrm{Si}_{8} \mathrm{O}_{24}\right] \cdot 2 \mathrm{NaCl}$, theoretically the $2 \mathrm{NaCl}$ component constitutes 12.49 wt.\%, which is comparable to the net loss in weight of about $10.0 \%$ obtained from the TG curve of tugtupite. Note that at the end of the experiment, weight loss was still taking place, as indicated by peak 4 in the DTG curve (Fig. 4b). However, this weight loss is not reflected in the corrected TG curve because the blank correction curve was truncated before $1450^{\circ} \mathrm{C}$, but the uncorrected TG curve (not shown) indicates the corresponding weight-loss peaks $4 \mathrm{a}, \mathrm{b}$; these data are included in Table 4 . In tugtupite, each weight-loss step is attributed to $\mathrm{NaCl}$, escaping at different rates. The tugtupite sample was run a second time, and the results obtained were the same.

In both tugtupite and sodalite samples, $\mathrm{NaCl}$ is liberated at different rates. In sodalite, the loss of $\mathrm{NaCl}$

TABLE 3. DATA DERIVED FROM TG, DTG, DTA, AND DDTA ANALYSES OF HALITE

\begin{tabular}{|c|c|c|c|c|c|c|}
\hline Peaks & Miscellaneous & TG & DTG & DTA & DDTA & Changes \\
\hline $\begin{array}{l}\text { Peak } 1 \\
(+) \text { ve } \dagger\end{array}$ & $\begin{array}{l}\text { Onset T }\left({ }^{\circ} \mathrm{C}\right) \\
\text { Peak T }\left({ }^{\circ} \mathrm{C}\right) \\
\text { End T }\left({ }^{\circ} \mathrm{C}\right) \\
\text { \% wt. loss } \\
\text { Enthalpy }(\mathrm{J} / \mathrm{g})\end{array}$ & -- & & $\begin{array}{r}795 \\
803 \\
821 \\
639.89\end{array}$ & $\begin{array}{l}801 \\
806\end{array}$ & Melting \\
\hline $\begin{array}{l}\text { Peak } 2 \\
(+) \text { ve }\end{array}$ & $\begin{array}{l}\text { Onset T }\left({ }^{\circ} \mathrm{C}\right) \\
\text { Peak T }\left({ }^{\circ} \mathrm{C}\right) \\
\text { End T }\left({ }^{\circ} \mathrm{C}\right) \\
\% \text { wt. loss } \\
\text { Enthalpy }(\mathrm{J} / \mathrm{g})\end{array}$ & $\begin{array}{r}766 \\
1083 \\
38.7\end{array}$ & $\begin{array}{l}802 \\
900 \\
949\end{array}$ & $\begin{array}{r}844 \\
877 \\
923 \\
21.84\end{array}$ & -- & $\begin{array}{l}\text { Loss of } \\
\mathrm{NaCl} \text { is } \\
\text { slow }\end{array}$ \\
\hline $\begin{array}{l}\text { Peak } 3 \\
(+) v e\end{array}$ & $\begin{array}{l}\text { Onset T }\left({ }^{\circ} \mathrm{C}\right) \\
\text { Peak T }\left({ }^{\circ} \mathrm{C}\right) \\
\text { End T }\left({ }^{\circ} \mathrm{C}\right) \\
\% \text { wt. loss } \\
\text { Enthalpy }(\mathrm{J} / \mathrm{g})\end{array}$ & $\begin{array}{r}1083 \\
1261 \\
59.5\end{array}$ & $\begin{array}{l}1018 \\
1182 \\
1194\end{array}$ & $\begin{array}{l}1005 \\
1182 \\
1193 \\
14.52\end{array}$ & 1188 & $\begin{array}{l}\text { Loss of } \\
\mathrm{NaCl} \text { is } \\
\text { more } \\
\text { rapid }\end{array}$ \\
\hline Total ${ }^{*}$ & Peaks 2 and 3 : & $w t . \%$ & & & & \\
\hline
\end{tabular}

* Total \% wt. loss (from start to end) is 99.0 , including 0.8 at the beginning. 
occurs in two continuous steps; in the first step, the loss of $\mathrm{NaCl}$ is slow, but in the second step, it is more rapid. However, in tugtupite, $\mathrm{NaCl}$ escapes in several steps at different rates. This difference in behavior may be related to the number of bonds with different strengths that have to be broken to liberate $\mathrm{NaCl}$. In sodalite, there are three $\mathrm{Na}-\mathrm{O}$ bonds of equal strength that have to be broken, but in tugtupite there are four $\mathrm{Na}-\mathrm{O}$ bonds with different strengths that have to be broken to liberate $\mathrm{NaCl}$ (Fig. 5). Moreover, the escape of $\mathrm{NaCl}$ from sodalite may occur more easily because of the larger $\beta$ cages $\left(V=701 \AA^{3}\right)$ in sodalite compared to those in tugtupite $\left(V=662 \AA^{3}\right)$.

In tugtupite, melting occurs at $1029^{\circ} \mathrm{C}$, which is $50^{\circ} \mathrm{C}$ lower than in sodalite. This difference in temperature may be attributed to more strain in the tugtupite framework, which contains three different types of $T$
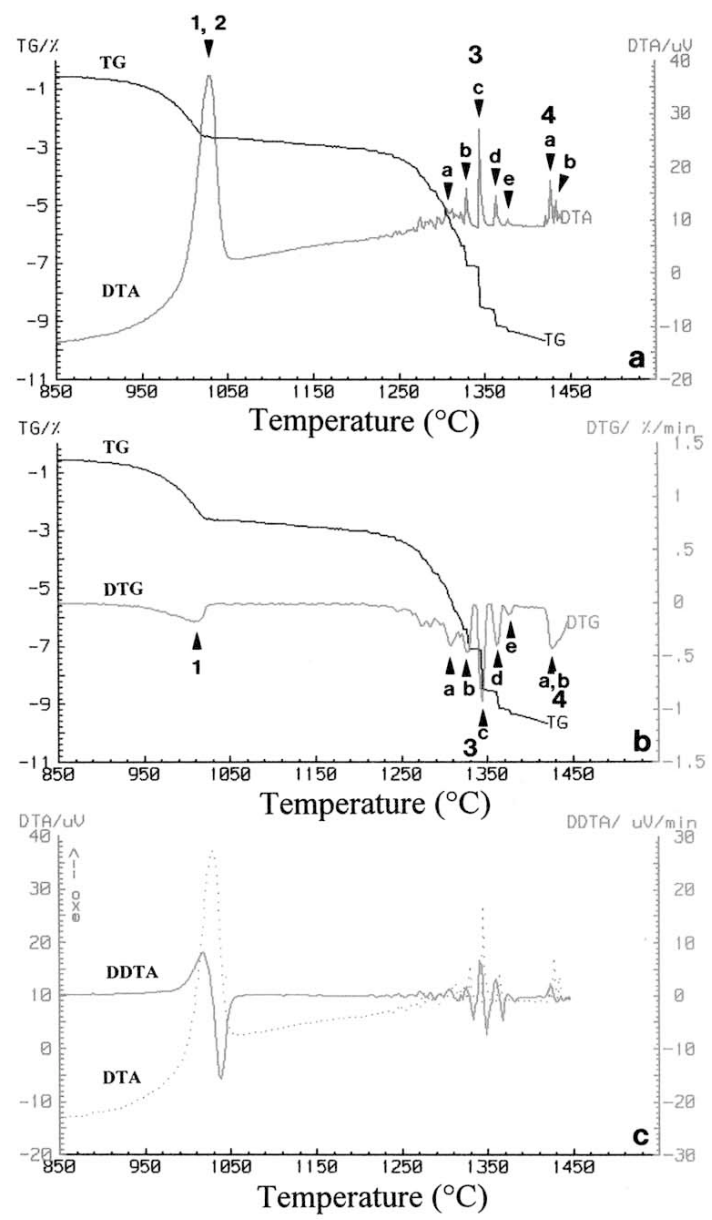

FIG. 4. Thermal curves for tugtupite: (a) TG and DTA curves, (b) TG and DTG curves, and (c) DTA and DDTA curves. atoms (Al, Be, Si) compared to two different types of $T$ atoms $(\mathrm{Al}, \mathrm{Si})$ in sodalite. The temperature at which tugtupite $\left(926^{\circ} \mathrm{C}\right)$ begins to lose $\mathrm{NaCl}$ is about the same as that in sodalite $\left(933^{\circ} \mathrm{C}\right)$, but the loss from the sodalite melt is stopped at about $1384^{\circ} \mathrm{C}$, whereas in the experiment on the tugtupite, the melt continues to lose $\mathrm{NaCl}$ beyond $1442^{\circ} \mathrm{C}$.

TABLE 4. DATA DERIVED FROM THE TG, DTG, DTA AND DDTA ANALYSES OF TUGTUPITE

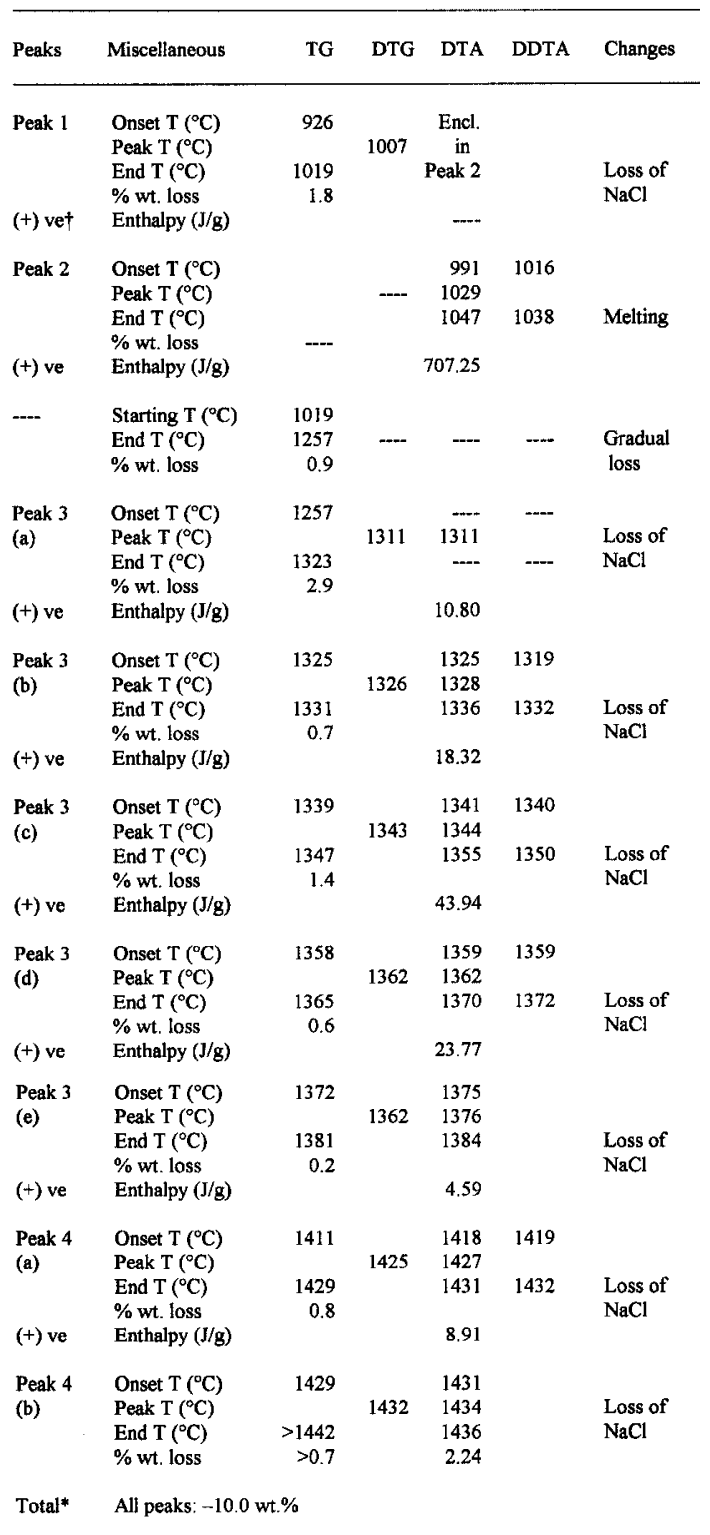

* Total wt. loss from start to end is $10,4 \%$. Note that peak 1 is enclosed in peak 2 . 
Danalite, $\mathrm{Fe}_{8}\left[\mathrm{Be}_{6} \mathrm{Si}_{6} \mathrm{O}_{24}\right] \mathrm{S}_{2}$

A sample of danalite from Mt. Francisco granitic pegmatite, Ribawa area, Western Australia (ROM \#M37261) was used is this study. The chemical data for a sample from the same locality are given in Table 1. This material was studied by Hassan \& Grundy (1985). For the thermal analyses, $102.0 \mathrm{mg}$ of the finely powdered sample was used. The thermal curves for danalite are shown (Fig. 6). In general, the TG curve indicates three main events, first a weight-gain event, followed by a weight-loss event, and finally another small weightgain event (Fig. 6a). The other thermal curves (Fig. 6) are more complex and contain many peaks, unlike the TG curve. Data obtained from these curves are summarized in Table 5.
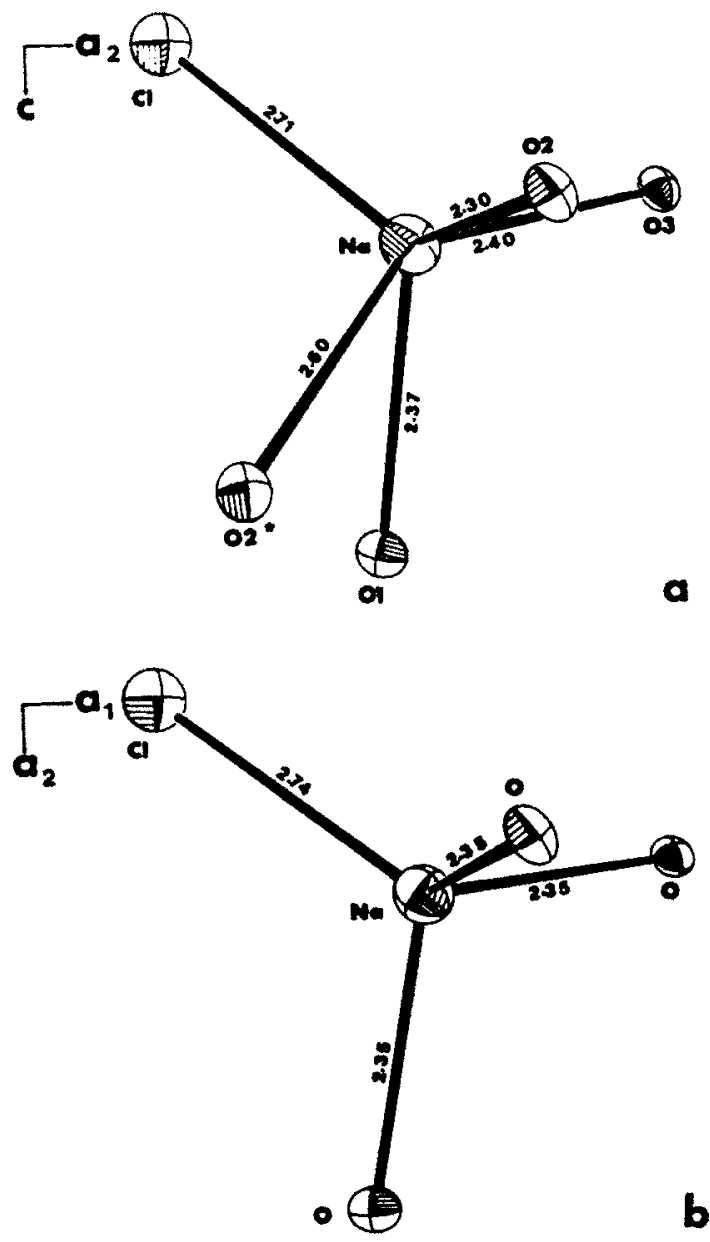

FIG. 5. Na atom coordinations: (a) five coordination in tugtupite, and (b) four coordination in sodalite.
Peaks 1, 2, and 3 in the DTA trace correspond to various rates of increase in weight as indicated by the TG curve (Fig. 6). Peaks 4, 5, 6, and 7 in the DTA curve are attributed to the loss of volatiles at different rates because of the continuous decrease in weight in the TG curve. The onset and end temperatures for all the peaks are better defined by the DDTA curve. Peak 7 at about $1274^{\circ} \mathrm{C}$ in the DTA trace is also related to the melting of danalite and is close to the end of the weight-loss event. Melt was observed in the crucible after the experiment.

Peaks 1, 2, and 3 in the DTG curve correspond to the first weight-gain stage, and from the TG curve a net gain of $4.0 \mathrm{wt} . \%$ is obtained (Fig. 6, Table 5). The gain in weight results from oxidation because the sample was heated in a static air environment. Therefore, divalent $\mathrm{Fe}^{2+}$ and $\mathrm{Mn}^{2+}$ oxidize to trivalent $\mathrm{Fe}^{3+}$ and $\mathrm{Mn}^{3+}$, respectively, at different rates. With complete oxidation, the theoretical formula of danalite (initially consisting only of $\mathrm{Fe}^{2+}$ ) would change from $\mathrm{Fe}^{2+}{ }_{8}\left[\mathrm{Be}_{6} \mathrm{Si}_{6} \mathrm{O}_{24}\right] \mathrm{S}_{2}$ to $\mathrm{Fe}^{3+}{ }_{8}\left[\mathrm{Be}_{6} \mathrm{Si}_{6} \mathrm{O}_{28}\right] \mathrm{S}_{2}$, and the theoretical increase due to the extra four $\mathrm{O}$ atoms would be $5.7 \mathrm{wt}$.\%. If the theoretical formula changed to $\mathrm{Fe}^{2+}{ }_{2} \mathrm{Fe}^{3+}{ }_{6}\left[\mathrm{Be}_{6} \mathrm{Si}_{6} \mathrm{O}_{27}\right] \mathrm{S}_{2}$, the theoretical increase due to the extra three $\mathrm{O}$ atoms would be $4.3 \mathrm{wt} . \%$. From the TG curve, a weight gain of 4.0 wt.\% is obtained, which corresponds to a theoretical increase of $2.8 \mathrm{O}$ atoms. This sample of danalite contains about equal amounts of $\mathrm{Fe}$ and $\mathrm{Mn}$, and a small
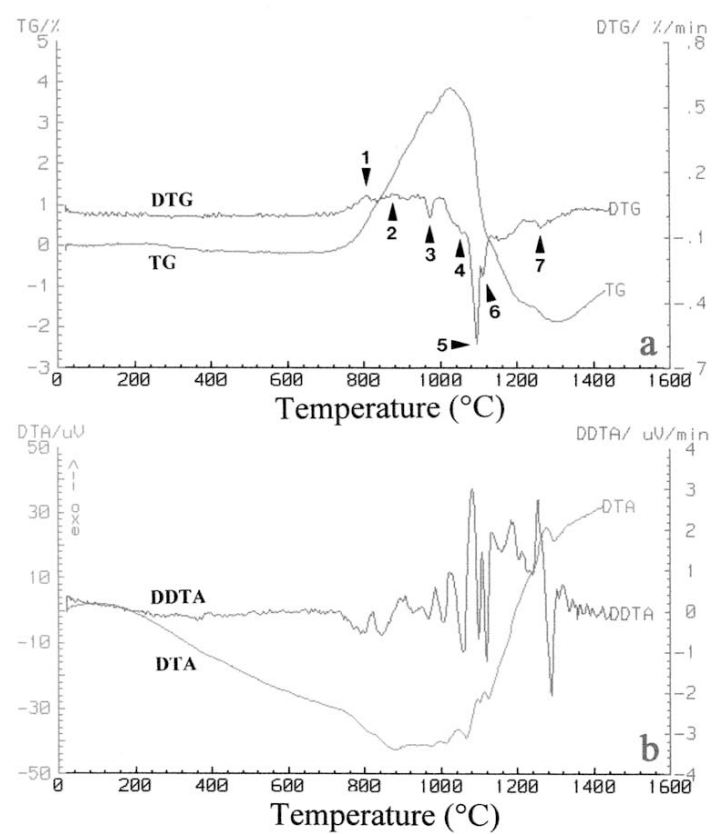

FIG. 6. Thermal curves for danalite: (a) TG and DTA curves, (b) TG and DTG curves, and (c) DTA and DDTA curves. 
amount of Zn, which will not be oxidized (Table 1). The $\mathrm{Fe}^{2+}$ first begins to oxidize to $\mathrm{Fe}^{3+}$ because of its lower oxidation potential $\left(+0.77 \mathrm{~V}\right.$ for $\mathrm{Fe}^{2+} \rightarrow \mathrm{Fe}^{3+}$ and +1.51 $\mathrm{V}$ for $\mathrm{Mn}^{2+} \rightarrow \mathrm{Mn}^{3+}$; Bard et al. 1985). Weight loss occurs over peaks $4,5,6$, and 7 in the DTG curve, and from the TG curve a net loss of $5.7 \mathrm{wt} . \%$ is obtained (Fig. 6, Table 5). Sulfur constitutes 5.73 wt.\% of danalite (Table 1), which is comparable to the weight loss obtained from the TG curve. Therefore, this weight loss is attributed to the loss of $S_{2}(\mathrm{~g})$ at different rates. In the weight-gain stage, $\mathrm{O}$ atoms are incorporated into the danalite structure, and in the succeeding weight-loss stage, instead of losing the incorporated $\mathrm{O}$ atoms, $\mathrm{S}$ atoms are lost as $\mathrm{S}_{2}(\mathrm{~g})$.

Beyond about $1297^{\circ} \mathrm{C}$, the TG curve begins to increases in weight again (incomplete peak 8 in the TG curve, Fig. 6a). An increase of 0.7 wt.\% is obtained up to $1450^{\circ} \mathrm{C}$ (Table 5). Possibly the trivalent $\mathrm{Mn}^{3+}$ begins to oxidize to tetravalent $\mathrm{Mn}^{4+}$. The peak temperature for this weight gain is beyond the experimental limit of $1450^{\circ} \mathrm{C}$; therefore, the DTG or DTA curve did not give a peak to indicate this increase in the TG curve.

In danalite, there is a weight gain caused by oxidation of $(\mathrm{Fe}, \mathrm{Mn})^{2+}$ to $(\mathrm{Fe}, \mathrm{Mn})^{3+}$ followed by a loss of $\mathrm{S}_{2}(\mathrm{~g})$, melting, and finally another weight-gain stage, possibly caused by further oxidation of $\mathrm{Mn}^{3+}$ to $\mathrm{Mn}^{4+}$ in the melt. During the first weight-gain event, which begins at about $771^{\circ} \mathrm{C}$, the $\mathrm{O}$ atoms incorporated possibly enter the cubo-octahedral cavities, and occupy a general site such that they are within bonding distance to the $\mathrm{Mn}$ or Fe atoms. Such a general site was found for the $\mathrm{O}$ atoms of $\mathrm{OH}$ and $\mathrm{H}_{2} \mathrm{O}$ in basic sodalite (Hassan \& Grundy 1983). If the $\mathrm{Mn}$ and $\mathrm{Fe}$ atoms fully oxidize to $(\mathrm{Fe}, \mathrm{Mn})^{3+}$, two $\mathrm{O}$ atoms are expected to enter each cubo-octahedral cavity. Thus, the original four-fold coordination of the $\mathrm{Mn}$ or Fe atom (tetrahedrally coordinated to three $\mathrm{O}$ atoms of the framework and one central $\mathrm{S}$ atom), probably increases to six, and the structure of danalite still remains intact. From about $1029^{\circ} \mathrm{C}$, each $\mathrm{Mn}$ or $\mathrm{Fe}$ atom, which is now bonded to one central S atom, three $\mathrm{O}$ atoms from the framework, and two incorporated $\mathrm{O}$ atoms, cannot retain the coordination number of six. The distance of the interframework cation, IC $(I C=\mathrm{Mn}, \mathrm{Fe})$ to $\mathrm{S}$, is longer than the $I C-\mathrm{O}$ bond distance $[I C-\mathrm{S}=2.413(1) \AA, I C-\mathrm{O}=2.033(3) \AA$; Hassan \& Grundy 1985]. Therefore, the longer $I C-\mathrm{S}$ bonds are broken, and $\mathrm{S}_{2}(\mathrm{~g})$ is liberated. The coordination of the $I C$ cation is now five, all the anions being oxygen atoms. The incorporated $\mathrm{O}$ atoms, however, do not occupy the positions of the $\mathrm{S}$ atoms, i.e., at the center and corners of the unit cell, because the $I C-\mathrm{S}$ bond in danalite is too long $[I C-S=2.413(1) \AA]$ to allow for reasonable $I C-\mathrm{O}$ bond distances. The incorporated $\mathrm{O}$ atoms are probably located off the center of the unit cell and are closer to the $I C$ cation to give proper $I C-\mathrm{O}$ bond distances. More $\mathrm{O}$ atoms can be incorporated into the danalite-derived melt with further oxidation of $\mathrm{Mn}^{3+}$ to $\mathrm{Mn}^{4+}$. Thus, the contents of some of the cages of tetra-
TABLE 5. DATA DERIVED FROM TG, DTG, DTA, AND DDTA ANALYSES OF DANALITE

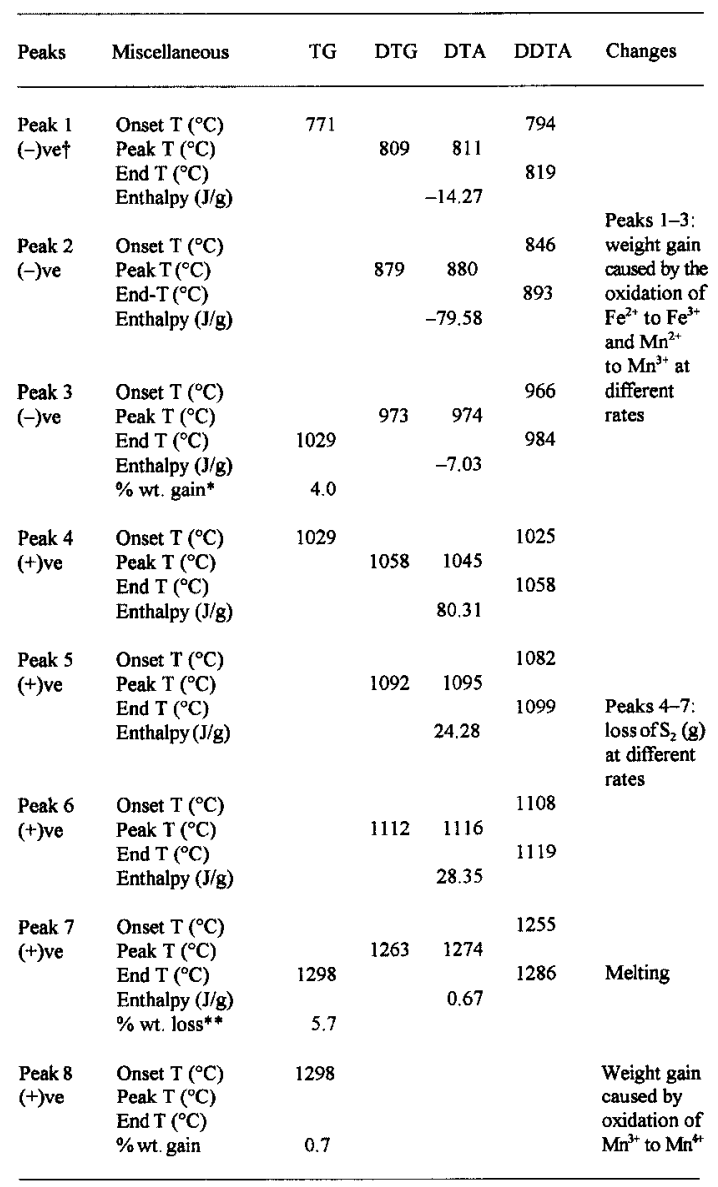

* Total wt. gain over peaks 1,2 , and 3 is $4.0 \%$. ** Total wt. loss over peaks 4,5 , 6 , and 7 is $5.7 \%$. Concerning the oxidation of $\mathrm{Mn}^{3+}$ to $\mathrm{Mn}^{4 *}$, see the text.

hedra change from $\left[(\mathrm{Mn}, \mathrm{Fe})^{2+}{ }_{4}^{\bullet} \mathrm{S}\right]^{6+}$ to $\left[(\mathrm{Mn}, \mathrm{Fe})^{3+}{ }_{4}\right.$ $\left.-\mathrm{SO}_{2}\right]^{6+}$ in the first stage of oxidation, with the net charge on the cage cluster remaining at +6 valence units. When danalite loses all of the $\mathrm{S}$ atoms, the cage clusters change to $\left[(\mathrm{Mn}, \mathrm{Fe})^{3+} 4^{\bullet} \mathrm{O}_{2}\right]^{8+}$. In this case, the net charge on the clusters $(+8$ valence units) does not balance the net change on the framework ( -6 valence units), so the danalite structure becomes unstable and the sample melts. To balance the excess of +2 valence units, more $\mathrm{O}$ atoms are required. Therefore, with further oxidation of the melt $\left(\mathrm{Mn}^{3+} \rightarrow \mathrm{Mn}^{4+}\right)$, the $\mathrm{O}$ atom content increases, the charge balances, and the melt becomes stable.

Helvite, $\mathrm{Mn}_{8}\left[\mathrm{Be}_{6} \mathrm{Si}_{6} \mathrm{O}_{24}\right] \mathrm{S}_{2}$

The helvite sample is from Sunnyside, San Juan County, Colorado (ROM \#M36390). In the thermal ex- 


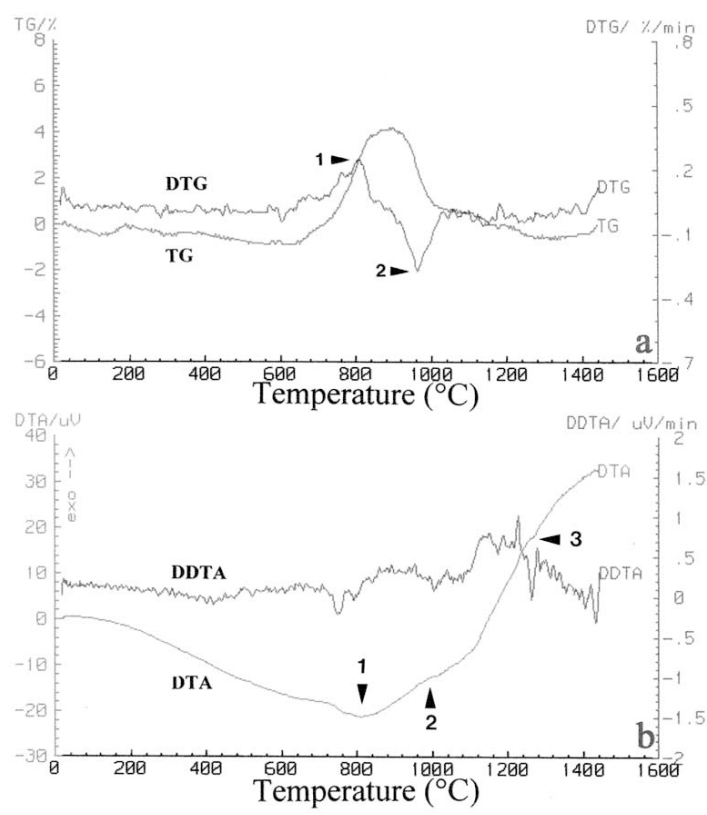

FIG. 7. Thermal curves for helvite: (a) TG and DTA curves, (b) TG and DTG curves, and (c) DTA and DDTA curves.

periment, only $20.7 \mathrm{mg}$ was used instead of about 100 $\mathrm{mg}$ of helvite, as more sample was unavailable. The theoretical chemical composition of pure helvite, $\mathrm{Mn}_{8}\left[\mathrm{Be}_{6} \mathrm{Si}_{6} \mathrm{O}_{24}\right] \mathrm{S}_{2}$, is given in Table 1. The thermal curves for helvite are shown in Figure 7. Data obtained from these curves are summarized in Table 6. In general, from the TG curve, there are two main stages; a weight-gain stage is followed by a weight-loss stage, as was found also in danalite. Two sharp peaks (1 and 2) in the DTG curve correspond to these two events. The DTA curve contains three small peaks $(1,2$ and 3$)$ possibly because of the small amount of sample. Peaks 1 and 2 in the DTA curve are related to weight gain and weight loss, respectively, because of the change in weight in the TG curve. Peak 3 occurs in the DTA trace at about $1260^{\circ} \mathrm{C}$, and there is no loss in weight in the TG curve; peak 3 thus is related to melting.

Peaks 1 and 2 are well defined in the DTG curve. The TG curve shows that there is a weight gain of 5.0 wt.\% over peak 1 (Fig. 7, Table 6). This gain in weight is caused by the oxidation of divalent $\mathrm{Mn}^{2+}$ and $\mathrm{Fe}^{2+}$ to trivalent $\mathrm{Mn}^{3+}$ and $\mathrm{Fe}^{3+}$, respectively. With complete oxidation, the theoretical formula of pure helvite (consisting only of Mn) would change from $\mathrm{Mn}^{2+}{ }_{8}\left[\mathrm{Be}_{6} \mathrm{Si}_{6}\right.$ $\left.\mathrm{O}_{24}\right] \mathrm{S}_{2}$ to $\mathrm{Mn}^{3+}{ }_{8}\left[\mathrm{Be}_{6} \mathrm{Si}_{6} \mathrm{O}_{28}\right] \mathrm{S}_{2}$; the theoretical increase due to the extra four $\mathrm{O}$ atoms is $5.8 \mathrm{wt} . \%$. From the TG curve, a weight gain of $5.0 \mathrm{wt} \%$ is obtained. This indicates a theoretical increase of 3.4 extra $\mathrm{O}$ atoms.
TABLE 6. DATA DERIVED FROM TG, DTG, DTA, AND DDTA ANALYSES OF HELVITE

\begin{tabular}{|c|c|c|c|c|c|c|}
\hline Peaks & Miscellaneous & TG & DTG & DTA & DDTA & Changes \\
\hline $\begin{array}{l}\text { Peak } 1 \\
(-) \text { ve } \dagger\end{array}$ & $\begin{array}{l}\text { Onset } \mathrm{T}\left({ }^{\circ} \mathrm{C}\right) \\
\text { Peak T }\left({ }^{\circ} \mathrm{C}\right) \\
\text { End T }\left({ }^{\circ} \mathrm{C}\right) \\
\% \text { wt. gain }\end{array}$ & $\begin{array}{l}705 \\
\\
883 \\
5.0\end{array}$ & 810 & 810 & $\begin{array}{r}793 \\
828\end{array}$ & $\begin{array}{l}\text { Weight gain } \\
\text { caused by } \\
\text { oxidation of } \\
\mathrm{Mn}^{2+} \text { to } \mathrm{Mn}^{3+} \\
\text { and } \mathrm{Fe}^{2+} \text { to } \\
\mathrm{Fe}^{3+}\end{array}$ \\
\hline $\begin{array}{l}\text { Peak } 2 \\
\text { (+)ve }\end{array}$ & $\begin{array}{l}\text { Onset T }\left({ }^{\circ} \mathrm{C}\right) \\
\text { Peak T }\left({ }^{\circ} \mathrm{C}\right) \\
\text { End T }\left({ }^{\circ} \mathrm{C}\right) \\
\% \text { wt. loss }\end{array}$ & $\begin{array}{r}883 \\
\\
996 \\
3.5\end{array}$ & 965 & 996 & $\begin{array}{r}992 \\
1004\end{array}$ & Loss of $S_{2}(g)$ \\
\hline $\begin{array}{l}\text { Peak } 3 \\
\text { (+)ve }\end{array}$ & $\begin{array}{l}\text { Onset T }\left({ }^{\circ} \mathrm{C}\right) \\
\text { Peak T }\left({ }^{\circ} \mathrm{C}\right) \\
\text { End T }\left({ }^{\circ} \mathrm{C}\right)\end{array}$ & & & 1260 & $\begin{array}{l}1225 \\
1261\end{array}$ & Melting \\
\hline
\end{tabular}

* Weight loss over peak 2 is $3.5 \%$, but it is a slow continuous loss, which occurs until about $1333^{\circ} \mathrm{C}$ giving a total of $4.7 \mathrm{wt} \%$. Beyond $1333^{\circ} \mathrm{C}$, there tends to be a small gain in weight (about 0.2 wt. \%).

Therefore, similar to the case for danalite, helvite undergoes oxidation, and contains extra incorporated $\mathrm{O}$ atoms. The TG curve gives a total weight loss of 4.7 wt.\% over peak 2 . This weight loss is attributed to the loss of $\mathrm{S}_{2}(\mathrm{~g})$, as in danalite. $\mathrm{S}$ constitutes $5.78 \mathrm{wt} . \%$ in the theoretical chemical composition of helvite (Table 6), but from the TG curve a weight loss of $4.7 \mathrm{wt} \%$ is obtained. Beyond about $1333^{\circ} \mathrm{C}$, the TG curve shows a small gain in weight of $0.2 \mathrm{wt}$. \%. At the maximum temperature, the DTG and DDTA curves also seem to indicate peaks corresponding to this weight-gain stage. However, since the experiment was terminated at $1450^{\circ} \mathrm{C}$, this weight-gain stage is not well defined. Therefore, in this minor weight-gain stage, possibly $\mathrm{Mn}^{3+}$ further oxidizes to $\mathrm{Mn}^{4+}$.

The DTG curve contains small peaks in addition to the two major peaks 1 and 2 (Fig. 7b); however, these small undulations are not really peaks, but noise, which arises because of the small amount of sample used (20.7 $\mathrm{mg})$. Larger filters (e.g., 101p) can smooth the DTG curve and eradicate most of the noise, but the peak temperatures obtained would not be accurate, so the use of larger filters was avoided.

In both danalite and helvite, first there is a weightgain stage, which begins at a temperature of about $705^{\circ} \mathrm{C}$ in helvite and about $771^{\circ} \mathrm{C}$ in danalite. This weight gain is caused by the oxidation of $(\mathrm{Fe}, \mathrm{Mn})^{2+}$ to $(\mathrm{Fe}, \mathrm{Mn})^{3+}$. Following this event there is a loss of $\mathrm{S}_{2}$ (g), which begins at $883^{\circ} \mathrm{C}$ in helvite and $1029^{\circ} \mathrm{C}$ in danalite. The weight gain and weight loss in danalite occur in several steps and at different rates, unlike those observed in helvite. The weight-gain stage in danalite was expected to occur at a lower temperature than that for helvite because of the lower oxidation potential of $\mathrm{Fe}^{2+}$ compared to that of $\mathrm{Mn}^{2+}$. However, the onset tem- 
peratures for both the weight loss and weight gain in helvite are lower than those observed for danalite. Melting occurs at about $1260^{\circ} \mathrm{C}$ in both samples. Finally, beyond about $1300^{\circ} \mathrm{C}$ there is further weight-gain, possibly caused by further oxidation of $\mathrm{Mn}^{3+}$ to $\mathrm{Mn}^{4+}$ in both melts formed. As helvite is Mn-rich, a larger weight-gain is expected for helvite in the second stage of oxidation, compared to danalite, because only the $\mathrm{Mn}^{3+}\left(\right.$ not $\left.\mathrm{Fe}^{3+}\right)$ can further oxidize to the +4 oxidation state. However, in this second stage of oxidation, the observed weight-gain in danalite $(0.7 \mathrm{wt} . \%)$ is more than that observed in helvite $(0.2 \mathrm{wt} . \%)$. The mechanism of incorporating $\mathrm{O}$ atoms into the structure, and losing $\mathrm{S}$ atoms, is the same in both danalite and helvite. Finally, this study shows that thermal techniques may be used to determine volatiles, oxidation states, and transition temperatures in minerals. This type of study may also have implications for studies concerning the degassing of magmas.

\section{ACKNOWLEDGEMENTS}

We thank the reviewers, Prof. Igor Khodakovskii, Drs. Irina Kiseleva, Elena Sokolova, and Robert F. Martin for useful comments.

\section{REFERENCES}

Bard, A.J., Parsons, R. \& Jordan, J. (1985): Standard Potentials in Aqueous Solutions. IUPAC, Marcel Dekker, New York, N.Y.

BARTH, T.F.W. (1926): Die kristallographische Beziehung zwischen Helvin and Sodalit. Norsk Geol. Tidsskr. 9, 4042.

BurT, D.M. (1980): The stability of danalite, $\mathrm{Fe}_{4} \mathrm{Be}_{3}\left(\mathrm{SiO}_{4}\right)_{3} \mathrm{~S}$. Am. Mineral. 65, 355-360.

Danø, M. (1966): The crystal structure of tugtupite - a new mineral, $\mathrm{Na}_{8}\left[\mathrm{Al}_{2} \mathrm{Be}_{2} \mathrm{Si}_{8} \mathrm{O}_{24}\right](\mathrm{Cl}, \mathrm{S})_{2}$. Acta Crystallogr. 20, 812-816.

DunN, P.J. (1976): Genthelvite and the helvine group. Mineral. Mag. 40, 627-636.
Hassan, I. (1996): The thermal behavior of cancrinite. Can. Mineral. 34, 893-900.

\& GRUNDY, H.D. (1983): Structure of basic sodalite, $\mathrm{Na}_{8} \mathrm{Al}_{6} \mathrm{Si}_{6} \mathrm{O}_{24}(\mathrm{OH})_{2} \cdot 2 \mathrm{H}_{2} \mathrm{O}$. Acta Crystallogr. C39, 3-5.

$\&$ (1984): The crystal structures of sodalite-group minerals. Acta Crystallogr. B40, 6-13.

\& (1985): The crystal structures of helvite group minerals, $(\mathrm{Mn}, \mathrm{Fe}, \mathrm{Zn})_{8}\left(\mathrm{Be}_{6} \mathrm{Si}_{6} \mathrm{O}_{24}\right) \mathrm{S}_{2}$. Am. Mineral. 70, 186-192.

$\&$ (1991): The crystal structure and thermal expansion of tugtupite, $\mathrm{Na}_{8}\left[\mathrm{Al}_{2} \mathrm{Be}_{2} \mathrm{Si}_{8} \mathrm{O}_{24}\right] \mathrm{Cl}_{2}$. Can. Mineral. 29, 385-390.

LÖNS, J. \& Schulz, H. (1967): Strukturverfeinerung von Sodalit, $\mathrm{Na}_{8} \mathrm{Al}_{6} \mathrm{Si}_{6} \mathrm{O}_{24} \mathrm{Cl}_{2}$. Acta Crystallogr. 23, 434-436.

Neuman, B.S. (1977): Thermal techniques. In Physical Methods in Determinative Mineralogy (J. Zussman, ed.). Academic Press, London, U.K. (605-662).

PAuling, L. (1930): The structure of sodalite and helvite. $Z$. Kristallogr. 74, 213-225.

PETERSON, R.C. (1983): The crystal structure of hackmanite, a variety of sodalite from Mont St-Hilaire. Can. Mineral. 21, 549-552.

TAYLOR, D. (1967): The sodalite group of minerals. Contrib. Mineral. Petrol. 16,172-188.

(1968): The thermal expansion of sodalite group of minerals. Mineral. Mag. 36, 761-769.

WeLlman, T.R. (1970): The stability of sodalite in a synthetic syenite plus aqueous chloride fluid system. J. Petrol. 11, 49-71.

Received February 11, 2001, revised manuscript accepted January 7, 2002. 